Nadporučík Karel Zetocha, Ph.D.

Výzbroj mechanizovaného vojska: jak dál s BVP-2 a vize rozvoje

Vojenské rozhledy, 2013, roč. 22 (54), č. 4, s. 81-90, ISSN 1210-3292

\title{
Armament of Mechanized Force: Keeping on BVP-2 and the Vision of Development
}

\section{Abstrakt:}

Článek je analýzou dalšiho rozvoje mechanizovaných praporů AČR. Rezort obrany se nachází před rozhodnutím, jak nahradit dosluhujicí BVP-2. Protože před několika lety bylo rozhodnuto o akvizici kolových BVP pro jednu brigádu, nyní je nejvýhodnějši na tento projekt dále navázat. Nákup a provozování kolových i pásových BVP zároveň, není pro armádu velikosti AČR vhodným řě̌ením. Vysoké náklady na provoz dvou podobných druhư techniky by nebyly dostatečně vyváženy nárůstem reálných schopností mechanizovaných jednotek. Autor předkládá radu argumentů pro podporu těchto tvrzení a v závěru dává doporučení pro akviziční strategii rezortu obrany do budoucna.

\section{Abstract:}

The article is an analysis of the further development of mechanized battalions of $C$ zech forces (ACR). The defence department will have to take a major decision how to replace old tracked infantry combat vehicles (ICVs) BVP-2. Several years ago, it was decided to acquire those vehicles for one brigade, so the best option could be to keep this project on. The acquisition and simultaneous operations of two similar vehicles, wheeled and tracked ones, are not effective for forces of ACR size. The extra costs of operation would not produce an adequate increase in capabilities of mechanized units. The author presents dozens of arguments to support this conclusion and at the end he makes recommendations for the future acquisition strategy in Czech defence department.

\section{Klíčová slova:}

Armáda České republiky (AČR), Bílá kniha obrany, mechanizovaná brigáda, vyzbrojování, akvizice, kolový, pásový, obrněný, bojové vozidlo pěchoty (BVP), BVP-2, KBVP Pandur.

\section{Key words:}

Army of the Czech Republic (ACR), White Paper on Defence, mechanized brigade, armament, acquisition, wheeled, tracked, armoured, infantry combat vehicle (ICV), BVP-2, WICV Pandur. 


\section{Úvod}

Bílá kniha o obraně z roku 2013 nejen nastínila základní strategickou rozvahu pro výstavbu AČR, ale zároveň zde byly formulovány některé zásadní otázky, které bude nutné v blízké budoucnosti řešit. Jednou z těchto otázek je další postup při vyzbrojování pozemních sil, kde jedním z největších otazníků zůstává náhrada zastarávajících bojových vozidel pěchoty. [1] Tato otázka se znovu dostala do středu pozornosti po veletrhu IDET 2013, kde byla obranným průmyslem prezentována možnost v podobě modernizace BVP-2.

Základní varianty řešení jsou všeobecně známé. Bojová vozidla pěchoty BVP-2 je možné je možné udržovat, modernizovat, nebo nahradit zcela novým typem techniky. $\mathrm{V}$ případě kompletní náhrady je nutné rozhodnout, zda nová technika bude na kolovém, nebo pásovém podvozku. Existují čtyři varianty řešení, přičemž všechny varianty mají své výhody i slabiny. Vzhledem k reálným finančním možnostem rezortu se zdá být nejpravděpodobnější, že bude rozhodnuto jen o dalším udržování stávajících BVP-2 v provozu. Tím ale bude jen oddáleno komplexnější rozhodnutí a v úvahu budou připadat již jen tři možnosti, které je možné zkráceně označit jako KBVP Pandur, BVP-2M (modernizované), nebo pořízení zcela nového typu pásového BVP.

Cílem následujícího textu je přispět do strategické debaty předcházející volbě nejvhodnějšího řešení. Pozornost bude věnována rozboru varianty kompletní náhrady BVP již zavedenou kolovou technikou. Varianta pokračování v projektu kolových vozidel je zatím ve strategické diskuzi neprávem opomíjena. V současnosti jsou úvahy o dalším nákupu KBVP ovlivněny řadou negativních zkušeností armády se zavedením tohoto druhu techniky. Nicméně do budoucna se jedná o variantu, která má i nesporné výhody, které nelze při formulování dlouhodobější vize pominout. V následujícím textu budou specifikovány argumenty, které podporují další pokračování projektu kolového BVP. Dále budou definovány výhody i nevýhody zmíněné varianty proti dalším dvěma řešením. V závěru budou shrnuty nejdůležitější argumenty a definována doporučení do budoucna.

\section{Pozemní vojsko, současný stav a vize rozvoje}

Jádrem pozemních sil AČR jsou v současnosti dvě bojové brigády: 4. brigáda rychlého nasazení „Obrany národa“, 7. mechanizovaná brigáda „Dukelská“ a národní specializace $\mathrm{v}$ podobě 31 . brigády radiační, chemické a biologické ochrany. Na tyto jednotky by proto mělo být soustředěno hlavní úsilí v procesu vyzbrojování. V následujícím textu je pozornost věnována situaci u dvou bojových brigád. Pro další argumentaci a uvedení současného stavu do souvislostí je nutný krátký pohled do nedávné historie.

Obě brigády vycházejí ze stejného základu mechanizované brigády, avšak rozdílný přístup k výstavbě obou jednotek v posledních dvaceti letech přinesl současný stav, kdy jsou obě brigády značně odlišné. Není cílem tohoto textu zabíhat do detailů, postačí jen dodat, že rozdílný přístup nastal s Koncepcí výstavby AČR z roku 1993, která byla realizována prostřednictvím transformace ukončené roku 1996. Z důvodů aktuální potřeby nasazovat tehdy ještě konskripčně doplňované jednotky koncepce předpokládala výstavbu jednotek rozdílné úrovně připravenosti. Konkrétně bylo rozhodnuto budovat různé druhy pozemních sil: síly rychlé reakce (poloprofesionální brigáda rychlého 
nasazení předurčená pro nasazení v zahraničí), polní vojsko (5 konskripčně doplňovaných mechanizovaných brigád tvořících jádro pozemních sil) a síly územní obrany (13 brigád, které by byly vytvářeny v př́ípadě mobilizace). [2]

Síly rychlé reakce (4. brigáda rychlého nasazení) prrirozeně získaly prioritu při vyzbrojování a doplňování, nebot’ vývoj mezinárodní situace ani nedovoloval jinak. Rostoucí intenzita a náročnost úkolů v zahraničí spojená s poklesem výdajů na obranu přinesly obrat $v$ akvizičním procesu rezortu obrany. Většina akvizice tak směřovala k uspokojení aktuálních potřeb zahraničních misí a na komplexnější obměnu výzbroje pozemních sil již nezbýval dostatek finančních prostředků.

Profesionalizace armády, trvalý pokles zdrojového rámce a nárůst angažovanosti ČR v zahraničních vojenských operacích jsou hlavními trendy, které formovaly současnou strukturu pozemních sil. Výsledkem procesu nutného přizpůsobování se AČR těmto trendům je současná situace, kdy jsou pozemní síly tvořeny dvěma odlišnými bojovými brigádami. Rozdílnost ve výzbroji obou brigád v základu vychází z prioritního financování jedné a následného nedostatku financí pro druhou.

Rozdělení mechanizovaných brigád na různé druhy (lehká, těžká, kombinovaná) vzešlo z Koncepce výstavby profesionální Armády České republiky a mobilizace ozbrojených sil České republiky z roku 2001. [3] Tato koncepce, která se záhy po svém vzniku stala nepoužitelnou (z rozpočtových důvodů), byla především reakcí na nečekané politické zadání v podobě požadavku na okamžité zahájení profesionalizace armády. Časový horizont zpracování koncepce ani neumožňoval provedení podrobnější strategické analýzy a diskuze (která např. předcházela vydání Bílé knihy o obraně z roku 2011). Rozdělení mechanizovaných brigád na lehkou a těžkou však přetrvalo i do budoucna. Avšak nelze se ubránit dojmu, že odkazy na zachování celého spektra schopností (budování lehké a těžké brigády) byly spíše snahou zpětně „strategicky“ zdůvodnit existující stav daný ekonomickou realitou, kdy rozpočtové zdroje neumožňovaly rovnoměrné vyzbrojování obou brigád.

Prostředky vyčleňované pro tzv. těžkou brigádu též do značné míry vyčerpávalo dědictví z devadesátých let v podobě nepovedeného projektu modernizace tanků T-72. Modernizační projekt na počátku provázely přemrštěné plány armádního velení podporované přehnaně sebevědomými ambicemi domácího obranného průmyslu. Obojí, společně se změnou mezinárodní situace, způsobilo, že v době dodání do AČR byly modernizované tanky, jakkoli kvalitní, nechtěným dítětem s velkými nároky na finanční zdroje.

Pro následující rozvahu je třeba jasně říci, že stávající rozdílná výzbroj posledních dvou bojových brigád není výsledkem dlouhodobé strategie rezortu, naopak vychází z neschopnosti dlouhodobě realizovat konzistentní strategii rozvoje. Současný stav je pozůstatkem strategie konce dvacátého století, výsledek nuceného přizpůsobování se realitě a nekonzistentnosti obranné politiky. Politické reprezentace např́ic politickým spektrem nebyly schopny dodržet vlastní opakované deklarace o výši financí vynakládaných na obrannou politiku. Rezort obrany na druhou stranu opakovaně spouštěl akviziční projekty, o jejichž smysluplnosti a př́nosu bylo možné od samého začátku pochybovat. Střednědobým cílem akvizičního procesu pozemních sil by proto nemělo být současný stav udržovat či dokonce prohlubovat, ale naopak obě brigády sbližovat. Nositelem specializace by do budoucna měl být u každé bojové brigády jen jeden prapor (výsadkový a tankový), zbytek sil by měl být postupně sjednocen. 
Intenzivní zapojení ČR do operace ISAF v Afghánistánu ukázalo, že obě bojové brigády musí být plně nasaditelné v zahraničí. Zároveň ukázalo, že jednotky obou brigád musí být schopny plnit stejné úkoly na stejné úrovni. Tomuto závěru, který je jasně doložitelný na základě posledních zkušeností, zcela odporuje reálná vybavenost a struktura pozemních sil.

Existence dvou bojových brigád s rozdílnou výzbrojí a strukturou neodpovídá současným strategickým potřebám ČR. Tento stav naopak komplikuje nasazování AČR do zahraničí, protože neumožňuje unifikovat přípravu jednotek a omezuje přenos získaných zkušeností.

\section{Vyzbrojování mechanizovaných praporů}

Projekt akvizice kolové bojové techniky do AČR již v minulosti oprávněně vzbudil mnoho vášní. Na základě známých faktů je dnes možné konstatovat, že akvizice pro AČR v nedávných letech provázela korupce v nejvyšších patrech politického rozhodování. Strategické koncepce, analýzy a především zájmy České republiky musely v mnoha případech ustoupit zájmům mocenských skupin, které měly blízko k vládnoucí politické garnituře. Z pohledu strategie dalšího směřování AČR již nemá smysl rozebírat, co mohlo být jinak, ale především hledat odpověd' na otázku, jakým způsobem stávající situaci co nejlépe využít. Jakkoli kolový obrněný transportér Pandur v dodaných verzích nemusí být nejlepším a jistě ne nejefektivnějším řešením, zavedení tohoto zbraňového systému do AČR je faktem, ze kterého musejí vycházet všechny další úvahy nad akvizicí výzbroje pro pozemní síly.

Při diskuzích o modernizaci BVP hovoříme de facto jen o dvou mechanizovaných praporech z celkového počtu čtyři. Legitimní otázka zní: Máme jednotlivé mechanizované prapory dále specializovat a nést tak zvýšení náklady zavedení většího množství rozdílné techniky? S přihlédnutím k ekonomické realitě a všem komplikacím, které by s sebou přineslo zavedení dalšího nákladného zbraňového systému, vychází jako racionální odpověd', že u armády velikosti AČR by měly být mechanizované prapory stejné.

Efektivní cestou pro zvládnutí širokého spektra operací není výstavba malého množství specializovaných jednotek, nýbrž výstavba jednotných univerzálních sil, které mohou být doplňovány specializovanými jednotkami (moduly) pro splnění konkrétní operace. Tento prŕístup odpovídá zásadám výstavby sil deklarovaným ve strategických dokumentech ČR i NATO.

Výstavba univerzálních a modulárních sil je ve strategických dokumentech deklarována již od přelomu tisíciletí. Naposledy tyto principy zmiňuje Obranná strategie České Republiky 2012, kde jsou vyjmenována kvalitativní kritéria pro rozvoj vojenských schopností. [4] Zavádění dvou rozdílných zbraňových systémů pro naplnění stejných, nebo velmi podobných schopností je v rozporu se současnou strategií výstavby sil na národní a alianční úrovni. Je ekonomickým nesmyslem zavádět rozdílnou výzbroj pro výstavbu stejných schopností při celkovém počtu čtyř mechanizovaných praporů. Vzhledem k rozpočtové realitě AČ́R by tento přístup ve svém důsledku omezil bojeschopnost pozemních sil jako celku (další vynucené škrty např. v oblasti zabezpečení, nebo výcviku). 


\section{Pandur verzus BVP-2}

Důležitou součástí rozhodování o akvizici výzbroje je analýza schopností. Je třeba jasně říci, že srovnávání schopností jednotlivých druhů techniky má jen omezenou vypovídající hodnotu. Důležité je definování schopností organizačních celků (jednotek) a schopnosti jednotlivých druhů techniky jsou pořizovány s ohledem na splnění cílových schopností celku. Není v možnostech tohoto textu provést komplexní rozbor schopností na patřičné úrovni, ani to není nutné k naplnění definovaných cílů textu.

Porovnání schopností kolového a pásového BVP je zde prezentováno za účelem demonstrace neúčelnosti zavedení dvou druhů techniky pro naplnění stejných schopností (viz tab.).

Tab.: Porovnání schopností kolových a pásových BVP

\begin{tabular}{lll}
\hline Schopnost & KBVP PANDUR & BVP-2 modernizované \\
\hline Přeprava pěšího družstva & ANO & ANO PLUS \\
\hline Pasivní ochrana posádky & ANO & ANO PLUS \\
\hline Aktivní ochrana posádky & NE & NE \\
\hline Palebná podpora pěchoty & ANO & ANO \\
\hline Boj proti obrněným cílům & ANO & ANO \\
\hline Překovávání vodních toků plaváním & ANO & NE \\
\hline Nasaditelnost & ANO PLUS & ANO \\
\hline Sběr a předávání informací & ANO & ANO \\
\hline
\end{tabular}

Z výše uvedeného porovnání je zřejmé, rozdíly ve schopnostech obou druhů techniky jsou minimální. Výhodou pásového BVP je vyšší průchodnost terénem a možnost vyššî balistické ochrany posádky. Výhodou kolového BVP je jeho nasaditelnost, tj. možnosti přepravy na bojišš̌ a univerzálnější použití v různých druzích konfliktů. Slabiny každého druhu techniky je ale možno vyvážit např. taktikou, organizací a výstavbou dalších druhů sil. Napřr. slabiny kolového BVP je možné vyvážit doplněním jednotek o vyprošt’ovací ženijní schopnosti. Stejně tak by bylo možné vyvážit slabiny pásových vozidel vhodným doplněním jednotek o další schopnosti, např. akvizicí výkonnějších přepravních letounů atd.

Všeobecně lze říci, že každý druh techniky má slabá místa, které je nutné vyvažovat doplněním sil o další schopnosti. Minimalizace vlastních slabin je navíc přirozenou součástí každého plánovacího procesu operace, jehož správné provedení může podstatně ovlivnit výsledek i zdánlivě rozhodnutého střetnutí. Vyvažování slabin zavedeného druhu techniky pomocí akvizice dalšího druhu techniky se stejným určením je možné, avšak jedná se o luxus, který si armáda velikosti AČR dávno nemůže dovolit. Do budoucna je jedinou únosnou cestou pro malé armády výstavba univerzálních sil s minimálním množstvím hlavních druhů techniky. Slabiny zavedené techniky bude nutné vyvažovat doplněním jednotek o specializované schopnosti a vývojem vlastních taktických postupů tak, aby byl vytvořen univerzálně akceschopný celek za minimálních možných nákladů. 


\section{Proč pokračovat v projektu Pandur}

Schválení nákupu KBVP Pandur v současné podobě (2009) do značné míry stanovilo mantinely pro budoucí akviziční procesy. Je jistě legitimní otázkou, zda mechanizované prapory nemají být vybaveny BVP na pásovém podvozku. Vybavení všech mechanizovaných praporů prostřednictvím mezinárodního projektu modernizace BVP-2 (který by navýšil celkový počet vyrobených kusů a maximalizoval tak přínos pro domácí obranný průmysl) byl zřejmě nejlepším z možných řešení. Avšak prostor pro takovéto rozhodnutí byl možná již uzavřen zavedením kolového BVP u poloviny jednotek mechanizovaného vojska. Další vhodná možnost pro zavedení BVP na pásovém podvozku (nejlépe prostř̌ednictvím společného mezinárodním projektu) znovu nastane nejdřive za tři desetiletí.

Varianta modernizace BVP-2 souběžně s již zavedenými KBVP by nutně přinesla požadavky na vývoj dalších specializovaných verzí bojových vozidel. Aby byla jednotka na pásovém podvozku kompaktní, je nutné doplnit standardní bojová vozidla minimálně o velitelské a průzkumné prostředky (pomineme-li prostředky ženijní, spojovací a zdravotní). Samostatný vývoj několika kusů vozidel ve specializovaných verzí by byl krajně neefektivní. Ve světle obrovských nákladů, které si vyžádal vývoj stejných specializací vozidel na kolovém podvozku, by se jednalo přímo o plýtvání omezenými finančními zdroji.

Jednou z hlavních výhod pokračování projektu Pandur je, že při šetrném nastavení parametrů je možné dosáhnout ceny za kus, která by umožnila zavedení jednotné techniky u co možná největšího počtu útvarů. V nejlepším případě by vedle pořízení KBVP zůstal prostor i pro investice do dalších schopností na jednotné platformě. Před AČR např. leží již zmíněné rozhodnutí o otázkách modernizace prostředků nepřímé palebné podpory. Jedná se o problematiku, která má dvě roviny: organické prostředky samotných mechanizovaných praporů a na vyšší úrovni pak výkonnější prostředky dělostřelectva. Při úvahách nad variantami náhrady BVP-2 dosud nebyl zmíněn fakt, že mechanizované vojsko nemá vyřešenou otázku palebné podpory jednotek. Přitom bez kvalitních prostředků nepřímé palebné podpory jsou schopnosti mechanizovaných praporů neúplné. $\mathrm{V}$ počáteční variantě projektu Pandur bylo počítáno i s pořízením kolových vozidel vybavených $120 \mathrm{~mm}$ minomety. Z důvodů nedostatku financí však bylo od realizace této části projektu upuštěno. Na tichém upuštění od záměru další akvizice měla svůj podíl i podezření z úplatkářství kolem nákupu KBVP Pandur, která se v roce 2010 dostala do pozornosti médií a orgánů činných v trestním řízení. [5]

Zároveň BVP-2 nejsou vybaveny jen mechanizované útvary, projekt jejich náhrady musí vzít v úvahu i vozidla, která jsou u útvarů dalších druhů vojsk. Kvalitní projekt řešení budoucnosti BVP-2 musí zahrnovat pokud možno nahrazení všech vozidel prostřednictvím jednoho akvizičního projektu rozloženého do delšího časového období. Soustředit se pouze na mechanizované útvary a následně realizovat samostatné projekty pro řešení zastarávajících BVP-2 u druhů vojsk by bylo chybou, která by otevírala prostor pro nekontrolované vršení dodatečných nákladů. Již při rozvaze způsobu náhrady BVP-2 je nutné provést ekonomickou analýzu celku, která bude zahrnovat i návaznost na další nutné modernizační projekty. Správně nastavené podmínky projektu náhrady BVP-2 by mělo umožnit realizovat komplexní řešení pro celé pozemní síly. Teprve při komplexním pohledu na problematiku vystoupí do popředí výhody unifikace výzbroje. 


\section{Kompromis pro budoucnost}

Konstatování, že by měla být BVP-2 nahrazena kolovými vozidly, zdaleka neznamená, že by na projekt Pandur mělo být bezezbytku navázáno v jeho stávající podobě. Naopak. Je žádoucí využít stávajících zkušeností s provozováním tohoto druhu techniky a pokračovat $\mathrm{v}$ jeho vývoji. Cílem vývoje by však nemělo být zvyšování schopností této techniky, ale paradoxně jejich snížení prostřednictvím nalezení kompromisních technických řešení. Kolové BVP v zavedených verzích dosáhlo v mnoha směrech stropu svých možností. Úkolem do budoucna není další extrémně drahé navyšování schopností, ale rozvíjení schopností již získaných, které by zároveň umožnilo pokles ceny za kus.

Projekt Pandur od samého počátku zahrnoval přemrštěné požadavky na schopnosti, které byly jedním z důvodů (vedle politické korupce) neúměrného prodražení zakázky. Ukázkovým př́kladem je schopnost plavání. Analýza charakteru konfliktů, z nich plynoucích úkolů a hrozeb, vedla armády NATO k soustředění pozornosti na balistickou ochranu posádky (která je v rozporu se schopností plavby). Schopnost plavby z hlediska současných priorit daleko vzadu a její absenci lze vyvážit efektivnějšími investicemi do schopností ženijních jednotek. Snaha skloubit v jednom druhu techniky protichůdné schopnosti (např. plavání a balistická ochrana) je extrémně nákladná a mnohdy nepřináší uspokojivé výsledky.

Další z možností jak významně snížit cenu vozidla je kompromisní rozložení palebných schopností mezi více vozidel. Otevřeně řečeno, mechanizované jednotky, kde je každé jedno vozidlo zapojeno do informačního systému, [6] a zároveň vybaveno palebnými prostředky na nejvyšší možné úrovni, včetně protitankových zbraní, jsou luxusem, který si AČR za současné situace může těžko dovolit. Cenou za vybavení části útvarů na nejvyšší úroveň je zastarávání dalších částí armády a v konečném důsledku způsobuje pokles akceschopnosti celku. Důležitou součástí plánování schopností je hledání př̀jatelných kompromisů, které umožní dlouhodobé udržení dostatečně vysokého stupně bojeschopnosti všech nasaditelných útvarů pozemních sil. Schůdnou cestou k umírnění nákladů je plné využití schopností již nakoupených KBVP Pandur a jejich doplnění o vozidla nižší kategorie. Konfigurace zavedených KBVP umožňuje jejich použití jako velitelských vozidel čety, které předává a zpracovává informace a zároveň poskytuje vysokou úroveň schopnosti ničení všech druhů pozemních cílů. Tato vozidla by mohla být doplněna o KBVP, jejichž schopnosti by se soustředily na ochranu a přepravu družstva pěchoty a na ničení lehčích cílů vzdálenost cca do 1500 m. Jelikož zbraňová stanice tvoří zásadní položku v ceně vozidla, její nižší konfigurace by zásadně mohla ovlivnit celkový účet za kus a otevřít cestu k nákupu dostatečného množství techniky. Právě mimořádné palebné schopnosti již nakoupených vozidel vybavených zbraňovým systémem s kanonem $30 \mathrm{~mm}$ a protitankovými střelami umožňují, aby společně s nimi působila i vozidla se zbraňovým systémem nižší kategorie a zároveň celek zůstal dostatečně schopný k vedení bojové činnosti. Nutno dodat, že nové zbraňové systémy jsou při zachování stejné ráže několikanásobně efektivnější a překonávají tak předchozí generaci i při nasazení celkově nižšího počtu zbraní.

Vytvoření unifikovaných mechanizovaných praporů může do budoucna přinést řadu pozitivních efektů, které jsou sice obtížně vyčíslitelné finančními prostředky, ale neméně důležité. Jako první se nabízí sjednocení výcvikové základny. Samotná akvizice techniky je jen nejviditelnější částí projektu, na kterou musí navázat rozpracování 
doktríny, taktických postupů, doporučení nejvhodnějších způsobů výcviku a bezpečnostních opatření. Každý nový zbraňový systém s sebou přináší nutnost přijmout úpravy doktrinálního systému, které se dále promítnou do řady pomocných dokumentů. AČR dosud nedokázala na úrovni doktríny a předpisů vstřebat řadu nově zavedené výzbroje posledních let. Unifikace techniky by byla příležitostí k dosažení vyšší úrovně systému př́ipravy, což by se následně mělo pozitivně promítnout i do úrovně bojeschopnosti jednotek. Shodná struktura mechanizovaných praporů by také umožnila jednodušší výměnu personálu mezi jednotkami a přispěla k realizaci systému kariérového růstu.

Největší přínos unifikace však leží v oblasti zabezpečení. Opětovné otevření projektu Pandur by bylo př́ležitostí k vyjednání nových podmínek údržby a zabezpečení techniky na základě již získaných zkušeností s jejím použitím. Zároveň by se tak otevřela možnost pro řešení technických nedostatků, které se projevily po zavedení vozidel do výzbroje. Větší množství provozované techniky by se teoreticky mělo odrazit i ve schopnosti zajistit údržbu techniky za nižší ceny. Totéž platí i pro nákup munice pro výcvik. Nákup špičkové techniky je neefektivní, pokud zároveň nedokážeme dlouhodobě zajistit prostředky k provádění oprav a akceptovatelné dodací lhůty těchto dílů. Je přijatelnější variantou dělat kompromisy při prvotní akvizici techniky a následně plně využívat jejích schopností, než nakoupit nejvyšší technickou úroveň a nechávat techniku odstavenou z důvodu nedostatku prostředků na opravy a problémy se zabezpečením dodávek náhradních dílů.

\section{Rozvoj AČR a domácí průmys|}

Pořízení nově vyvinuté techniky v sobě obsahuje i vícenáklady v podobě odstávek techniky a dořešení nedostatků, které odhalí až operační provoz. Každý výrobce přirozeně především propaguje technické výkony nové techniky proti starším verzím a technické komplikace (které jsou při vývoji nového systému pravidlem) se zavedením operačně nevyzkoušené techniky bagatelizuje. Státy velikosti ČR by se samostatně neměly pouštět do dobrodružství v podobě prvotního zavedení nově vyvinuté techniky, protože na nutné další úpravy techniky nemají dostatek financí, ani vlastních kapacit.

Samostatný vývoj specializovaných verzí techniky má pro malé státy taktéž své meze. Je třeba jasně říci, že zájmy domácího obranného průmyslu nejsou přirozeně shodné se zájmy armády. I zde je nutné hledat kompromisy a sladit rozdílné požadavky obou stran. Zapojení do mezinárodních projektů je náročnou, ale do budoucna perspektivní cestou jak zajistit setrvalý rozvoj za přijatelné ceny. [7]

Domácí výrobci se mnohdy snaží ve vlastním zájmu lobovat za spuštění národních projektů vyzbrojování, avšak pro ČR se v současnosti jedná o překonaný a do budoucna neudržitelný př́ístup. Na vybraných projektech lze jasně doložit, že pokud se již podaří na národní úrovni realizovat kvalitní projekt a zavést jej do výzbroje, AČR jen obtížně financuje jeho plnohodnotný provoz, přičemž na další vývoj již nezbývají peníze. Argumenty o benefitech pro státní rozpočet v podobě exportu se častěji ukázaly být pouhým přáním než realitou mezinárodního obchodu s obranným materiálem.

Konkrétní domácí výrobce musí být nejprve schopen samostatně zajistit vlastní ekonomické přežití a realizovat prodeje na mezinárodním trhu. Zakázky od AČR jsou již natolik omezené, že samostatně nedokážou dlouhodobě zajistit ekonomickou stabilitu a rozvoj žádné firmy. Poskytování zakázek AČR ekonomicky nesoběstačným firmám 
jen oddaluje restrukturalizace, které je nutné učinit. Zakázka AČR by pro firmu měla být cestou $\mathrm{k}$ dalšímu rozvoji vlastního úspěchu, nikoliv záchranným kruhem pro „,tradičního" výrobce.

\section{Závěr}

Projekt přezbrojení části pozemních sil na KBVP byl dokončen a je na další desítky let nezpochybnitelnou realitou. Otázka do budoucna zní jak nejlépe využít jeho předností a vyvážit slabá místa. Jednou z možných cest je využití získaných zkušeností pro další pokračování v projektu. Samozřejmě mohou nastat skutečnosti (např. na straně výrobců KBVP Pandur), které pokračování projektu postaví mimo realitu. Avšak v rovině strategické rozvahy by měly být rozpracovány všechny možnosti. Varianta kompletního přezbrojení na kolovou techniku má za daných okolností i své nesporné výhody a nebylo by moudré, ji předem zavrhnout bez kvalitní analýzy dostupných dat.

Prosté porovnávání schopností jednotlivých zbraní a zbraňových systémů má pouze omezenou vypovídací hodnotu. To co rozhoduje o úspěchu či neúspěchu operace jsou schopnosti celku. Pořízení sebevýkonnějšího zbraňového systému nebude mít patřičný efekt, pokud není doplněno dlouhodobým (finančními zdroji podloženým) programem zabezpečení logistiky a výcviku. Př́lišs nákladná modernizace jedné části armády může mít za následek pokles akceschopnosti celku, pokud př́liš ambiciózní projekt způsobí zaostávání jiných specializovaných částí. Ne zcela povedené akviziční projekty minulosti již nelze vzít zpět a jedinou možnou cestou je navázat na jejich silné stránky a další akvizicí je rozvíjet.

Dvě bojové brigády AČR by do budoucna měly směřovat k unifikaci. Zkušenosti z posledního nasazení v Afghánistánu jasně ukazují, že obě jednotky musí být schopny plnit stejné úkoly. Rozdělování bojových jednotek na síly předurčené k obraně vlastního území či nasazení v zahraničí je překonanou minulostí. Jediným východiskem do budoucna je budování univerzálních sil, které jsou schopné plnit bojové i nebojové úkoly doma i v zahraničí.

Státy velikosti ČR jsou při budování ozbrojených sil postaveny před dilema, zda pořizovat menší množství techniky nejvyšší možné úrovně, nebo již při specifikaci cíleně omezovat požadavky na schopnosti konkrétních druhů techniky. Trend nárůstu ceny výzbroje spojený s poklesem politické vůle alokovat finanční prostředky na zajištění obrany státu vytváří propast mezi požadavky na vybavení a ekonomickými možnostmi armády tyto požadavky uspokojovat. Rozdíl mezi cenou nejmodernější techniky a reálným rozpočtem se bude do budoucna dále prohlubovat. Omezování celkového počtu bojových jednotek má své hranice a současná AČR této hranice již dosáhla, což taktéž jasně dokládá poslední zkušenost se skládáním kontingentů do mise ISAF. Cestou z dilematu je cílené hledání kompromisů při stanovování požadavků na akvizici, unifikace výzbroje a prohlubování mezinárodní spolupráce.

Schopnosti jednotek zdaleka nejsou založeny jen na výzbroji. Schopnost se skládá z řady proměnných, které jsou dle vzoru USA označovány zkratkou DOTMLPFI (doktrína, organizační struktura, příprava osob, materiál, úroveň vedení, personál, infrastruktura a interoperabilita). Výzbroj (součást proměnné materiál) je však zdaleka nejdražší položku při výstavbě schopností. Uchopení schopností v plném rozsahu významu slova 
zároveň znamená, že nedostatky v některé z oblastí je možné vyvažovat excelencí $\mathrm{v}$ jiných oblastech.

Armáda ČR již nikdy nebude v pozici, kdy by mohla excelovat v oblasti materiálního vybavení. Pokud toto omezení přijme a dokáže dosáhnout excelence v jiných oblastech (kde je to podstatně levnější), stále může být schopna držet krok se svými spojenci i nepřáteli a uspět při plnění současných i budoucích úkolů. V historii lze najít řadu př́kladů, kdy armáda s technicky slabší výzbrojí dokáže zvítězit v přímé konfrontaci s teoreticky silnějším protivníkem. Základem úspěchu je volba správné strategie ve spojení s precizně prováděnou taktikou, úroveň vedení ve spojení s promyšleným výcvikem a odhodlaností personálu na všech úrovních vojenské organizace. To vše jsou položky, které lze jen obtížně vyjádřit penězi, ale jejich dosahování je jistě levnější než nákup nejmodernějších dostupných zbraní.

\section{Poznámky a seznam literatury:}

[1] Bílá kniha o obraně, Praha: Ministerstvo obrany České republiky-OKP MO, 2011. 168 s. ISBN 97880-7278-563-3.

[2] Viz TŮMA, Miroslav - JANOŠEC, Josef - PROCHÁZKA Josef. Obranná politika Československé a České republiky (1989-2009). Praha: PIC MO, 2009, 232 s. ISBN 978-80-7278-522-3, s. 41-43.

[3] Koncepce výstavby profesionální Armády České republiky a mobilizace ozbrojených sil České republiky. Praha: Ministerstvo obrany České republiky, 2001, 55 s.

[4] Obranná strategie České Republiky - odpovědný stát a spolehlivý spojenec. Praha: OKP MO, 2012, 12 s. ISBN 978-80-7278-606-0.

[5] Náměstek ministra dohadoval provizi za stamilionovou zakázku, Idnes [online], 31. srpna 2010, [cit. 2013-08]. < http://zpravy.idnes.cz/namestek-ministra-dohadoval-provizi-za-stamilionovou-zakazkupvp-domaci.aspx?c=A100831_210528_domaci_mad $>$.

[6] Vývoj a realizace informačních systémů pro podporu velení a řízení v podmínkách AČR je samostatnou kapitolou a vyžadoval by zvláštní analýzu. Porovnání dosud vynaložených a plánovaných nákladů na systémy C2 s reálným nárůstem schopností bojových jednotek by zřejmě bylo neradostným čtením. Budovat mobilní informační sítě od nejnižší úrovně má smysl, pokud zároveň dokážeme uspokojit (finančně pokrýt) základní potřeby bojových jednotek. Nákup nejmodernějších informačních zařízení nepřinese očekávaný efekt nárůstu schopností, pokud nebudou jednotně zavedeny u všech bojových jednotek a pokud zároveň nebudou spolehlivě zajištěny základní schopnosti jednotek. Zjednodušeně řečeno, bez informačního terminálu v každém vozidle stále dokážeme velmi efektivně bojovat, bez náhradních dílů a munice nikoliv.

[7] Budoucí rozvoj obranné průmyslové základny (pokud je v současné době ještě smysluplné tento termín vůbec používat) a armádní akvizice vyžadují rozsáhlejší odbornou diskuzi. Autor sdílí názor Viléma Kolína, že je třeba ,dělat věci jinak“ avšak vzájemně prospěšné propojení zájmů obranného průmyslu a armády je mimořádně složitým úkolem, který teprve čeká na své řešení. Základní podmínkou úspěšného řešení je vyloučení politické korupce z obranného akvizičního procesu. K doporučením pro budoucí směřování akvizičního procesu MO viz KOLÍN, Vilém. Hospodárný, efektivní a udržitelný rozvoj vojenských schopností ČR: zbožné přání nebo politická nutnost? Obrana a strategie [online]. 2010, roč. 10, č. 2, ISSN 1802-7199 [cit. 2013-08]. Dostupné z < http://www.defenceandstrategy.eu/ cs/aktualni-cislo-2-2010/volna-tribuna/hospodarny-efektivni-a-udrzitelny-rozvoj-vojenskych-schopnosti-cr.html\#.Uhe2nz8rrIU>. 